\title{
Effect of nitrogen level on growth and yield attributing characters of radish
}

\begin{abstract}
Radish is one of the well-known root crops that belong to family Brassicaceae. Its popularity could be due to its wider climatic adaptation, easy cultivation methods and wider ranges of its uses. The cultivar "Minow Early" was selected for experiment. Field trial was conducted on horticultural farm of Lamjung campus between OctoberJanuary 2017/18 in Randomized Complete Block Design with four replications and five treatments to assess the role of five different levels of nitrogen $(100,150,200$, 250 and $300 \mathrm{~kg}$ per ha) application on growth and yield attributes of Radish. The different growth and yield parameters like plant height, number of leaves, root length, root girth, root weight were measured. Significant differences were found on root length and plant height. Maximum root length and plant height was observed at 250 and $300 \mathrm{~kg}$ per ha reflecting better yield performance in these levels of nitrogen. This indicates that $250 \mathrm{~kg}$ per ha of nitrogen was best for better yield (mean root weight $=121.3 \mathrm{~g}$ per plant $)$.
\end{abstract}

Keywords: doses, favorable, growth; plant response, root yield
Volume 2 Issue 4 - 2018

\author{
Poudel P,' Shrestha A,' Shrestha RK ${ }^{2}$ \\ 'Technical Officer, Department of Plant Breeding and Genetics, \\ Nepal Agriculture Research Council, Nepal \\ ${ }^{2}$ Department of Plant Protection, IAAS, Nepal
}

Correspondence: Poudel P, Department of Plant Protection, IAAS, Lamjung Campus, TU, Nepal,

Email poudelpratima08@gmail.com

Received: July 20, 2018 | Published: August 28, 2018

\section{Introduction}

Radish (Raphanussativus L.) is one of the well-known root vegetable crops. It is grown as annual or biennial plants that belongs to family Brassicaceae and genus Raphanus. It is mainly grown for its succulent taproot. It has low caloric value in both root and leaves. In Nepal, the area under radish cultivation is $16915.7 \mathrm{ha}$, its production $268119.6 \mathrm{mt}$ and its productivity $15.9 \mathrm{~m} / \mathrm{ha}$. It can be successfully grown throughout the year in the hills of Nepal. ${ }^{1}$ Its popularity could be due to its wider climatic adaptation, easy cultivation methods and wider ranges of its uses. Nitrogen is a paramount element for plant since it is a core component of many plant structures and for both their internal and external metabolic (Greenway Biotech, Inc. (Accessed via:https://www.greenwaybiotech.com/blogs/news/whats-thefunction-of-nitrogen-n-in-plants. May 18, 2018. 10:25am). Healthy plants often contain 3-4\% nitrogen in their above-ground tissues. This is a much higher concentration compared to other nutrients. Among macro nutrients nitrogen plays a vital role in the growth and development of plants. It is an essential constituent of metabolically active compounds like protein, nucleic acids, chlorophyll and enzymes etc. When nitrogen is deficient in soil, the harvest is poor in size, weight and quality. ${ }^{2}$ Nitrogen fertilization is widely adopted to enhance crop production and improve nitrogen utilization all over the world. Among the factors deciding about successful cultivation of this vegetable nitrogen fertilization is of a special meaning and application level of this element should be targeted not only on the yield size, but, first of all, yield. ${ }^{3}$ The role of nitrogen is acceptable as it is a necessary component of protein nucleic acids, chlorophyll and certain important enzymes. ${ }^{4}$ On the other hand, deficiency of nitrogen in soil results into poor crop yield with low quality. While, excessive use of negatively affects the quality as well as yield of agricultural crops. Nitrogen is very essential for leafy vegetable production. ${ }^{5}$ Its application upholds the overall growth, yield and quality of radish. The application according to the government recommendation and application according to the farmers is totally different. Farmers thinks Urea as only one fertilizers source for the crop growth which is considered to be factor directly or indirectly involving in effecting the total yield of radish.

\section{Materials and methods}

Field trial was conducted on horticultural farm of Lamjung Agriculture Campus, Lamjung, Nepal(latitude: 28.125896; longitude: 84.416133 and altitude: $630.02 \mathrm{~m}$ ) between October-January 2017/18 on radish following single factorial Randomized Complete Block Design with four replications and five treatments. Different dose of Nitrogen viz. $50 \%, 75 \%, 100 \%, 125 \%$ and $150 \%$ of government recommended dose were evaluated for their field efficacy in growth and yield attributes of Radish. Government recommended dose of NPK is 200:180:60kg/ha respectively (Krishi Diary 2074). Full dose of $\mathrm{P}$ and $\mathrm{K}$ while $50 \%$ of $\mathrm{N}$ was supplied during sowing while remaining $\mathrm{N}$ was supplied in equal proportion in 30 and 45 days after sowing. $1.28 \mathrm{~kg}$ well rotten farm yard manure (Krishi Diary 2074) was applied per plot before sowing. Irrigation was applied frequently during germination period and after this period, scheduled in the intervals viz. 3 days and 5 days as per the soil moisture condition. Plots were partitioned at the distance of $50 \mathrm{~cm}$. The radish cultivar Minow Early, widely grown in this locality was used for the trial. The plot size was maintained at $0.8 \times 0.8 \mathrm{~m}$ holding 16 plants per plot keeping row to row distance as $20 \mathrm{~cm}$ and plant to plant distance $20 \mathrm{~cm}$. 4 plants per plot were under observation. Different growth and yield parameters were recorded. Plant height was taken from the point of root attachment to the top of the leaves. Root length was recorded by measuring the length of white part of root and the means were worked out and expressed in centimeter. Root girth refers to the average width at the widest point in the middle portion of mature root. Root weight was taken with the help of weighing balance. The data were analyzed statistically using computer package program SPSS version16.0 and R-STAT. Homogeneity test was conducted. Mean separation was done using Least Significant Difference (LSD) and Duncan's Multiple Range Test(DMRT) at 5\% significance level. ANOVA were done at $1 \%$ and $5 \%$ level of significance or mean comparison. The correlation between root length and $\mathrm{N}$ level, plant height and $\mathrm{N}$ level were calculated and graphed using SPSS. 


\section{Result and discussion}

\section{Growth attributing characters}

\section{Effect of nitrogen level in plant height}

Highly Significant results of Plant height for different nitrogen levels were observed. Highest plant height was observed in $250 \mathrm{Kg} /$ haN $(49.875 \mathrm{~cm})$ which is statistically at par with $200 \mathrm{Kg} / \mathrm{ha}$ and $300 \mathrm{Kg} / \mathrm{haN}$. Minimum plant height was observed in $100 \mathrm{Kg} / \mathrm{haN}$ that is statistically at par with $150 \mathrm{Kg} / \mathrm{haN}$. Similar results were obtained by Sharma and Kanuzia. Height of plant can be considered as one of the indices of plant vigor ordinarily and it depends upon vigor and growth habit of the plant. Soil nutrients are also very important for the height of plants. So, higher dose of nitrogen increased plant height. These results are in conformity with the findings of Sharma and Rastogi et al. ${ }^{6}$ Plant height is an indicator of vegetative growth. Minimum plant height might be due to the result of unavailability of nitrogen and other nutrients required by the plants for their normal growth and development. It was observed that an increase in nitrogen levels positively affected the plant height character which might be due to the role of nitrogen for cell division, cell enlargement and protein synthesis characteristics. An improvement in plant height with increasing nitrogen applications has also been confirmed with the findings of Balooch et al $^{7}$ (Figure 1).

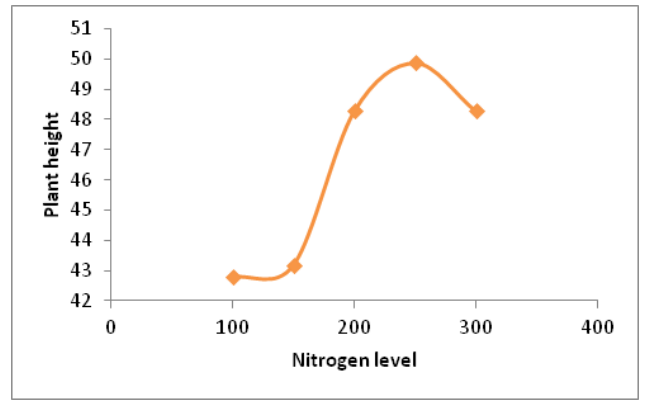

Figure I Relationship between plant height and different nitrogen level of radish at Lamjung Agriculture Campus, Lamjung, Nepal during Oct 2017- Jan 2018.

\section{Effect of nitrogen level in number of leaves}

Data for number of leaves spelt out non-significant results. However, it shows some trend for different nitrogen levels indicating superiority of $300 \mathrm{~kg} / \mathrm{ha}$ and $250 \mathrm{~kg} / \mathrm{ha}$ over other treatment. $300 \mathrm{~kg} / \mathrm{ha}$ and $250 \mathrm{~kg} /$ ha produced 20.125 number of leaves per plant, respectively (Table 1). Similar results were obtained by Sharma \& Kanaujia. ${ }^{8}$ These results are also confirmed by the findings of Shrivastava et al. ${ }^{9}$ The leaves are the plant factories, manufacturing carbohydrates. The photosynthesis occurs in leaf cells and carbohydrates are formed there. Vegetative growth was increased with increase in Nitrogen level.

Table I Effect of different levels of nitrogen on yield parameters of Radish at Lamjung Agriculture Campus, Lamjung, Nepal during Oct 2017- Jan 2018

\begin{tabular}{|c|c|c|c|c|c|}
\hline \multicolumn{3}{|c|}{ Nutrients (Kg/ha) } & \multicolumn{3}{|c|}{ Yield parameters } \\
\hline $\mathrm{N}$ & $P$ & K & Root Weight & Root Girth & $\begin{array}{l}\text { No. of } \\
\text { leaves }\end{array}$ \\
\hline 100 & 180 & 60 & $0.1290^{\mathrm{a}}$ & $12.242^{\mathrm{a}}$ & $19.062^{\mathrm{a}}$ \\
\hline 150 & 180 & 60 & $0.1180^{\mathrm{a}}$ & $11.087^{a}$ & $20.062^{\mathrm{a}}$ \\
\hline 200 & 180 & 60 & $0.1095^{a}$ & $10.587^{a}$ & $20.087^{a}$ \\
\hline 250 & 180 & 60 & $0.1213^{a}$ & $11.882^{\mathrm{a}}$ & $20.125^{a}$ \\
\hline 300 & 180 & 60 & $0.1043^{a}$ & $10.83^{a}$ & $20.125^{\mathrm{a}}$ \\
\hline
\end{tabular}

Table continued.

\begin{tabular}{llll}
\hline Nutrients (Kg/ha) & \multicolumn{3}{c}{ Yield parameters } \\
\hline Significant & NS & NS & NS \\
LSD & 0.044 & 1.937 & 2.219 \\
CV & 24.82 & 11.105 & 7.243 \\
SEm $( \pm)$ & 0.0008 & 1.582 & 2.076 \\
Grand Mean & 0.116 & 11.326 & 19.892 \\
\hline
\end{tabular}

$N S=$ Non-significant, $L S D=$ Least Significant Difference, $C V=$ Coefficient of Variation, SEm $( \pm)=$ Standard Error of Mean, Means followed by the same letters in a column are not significantly different by DMRT at $5 \%$ level of significance

\section{Yield attributing characters}

\section{Effect of nitrogen level in root length}

Nutrient levels had exerted very significant effect on length of root. Mean values in relation to different nitrogen levels indicated significant superiority of $300 \mathrm{Kg} / \mathrm{haN}$ over other treatments. 300 $\mathrm{Kg} / \mathrm{ha} \mathrm{N}$ produced maximum root length of $24.012 \mathrm{~cm}$ which is statistically at par with $250 \mathrm{Kg} / \mathrm{ha}(23.769 \mathrm{~cm})$ and $200 \mathrm{Kg} / \mathrm{ha}$ $(22.537 \mathrm{~cm}) .200 \mathrm{Kg} / \mathrm{ha} \mathrm{N}$ is also statistically at par with $100 \mathrm{Kg} / \mathrm{ha} \mathrm{N}$ and $150 \mathrm{Kg} / \mathrm{ha} \mathrm{N}$. Minimum root length was produced by treatment $100 \mathrm{Kg} /$ ha i.e. $20.996 \mathrm{~cm}$. An increase in root length might be due to effect of environment, soil texture and on time and balanced manuring practices. Similar results were also explained by Nargave $\mathrm{K}^{10}$ that nitrogen level have significant influence on root length. These results are in accordance with Parrhasarathi et al., ${ }^{11}$ and Pervez et al. ${ }^{4}$ There could be attributed to the positive influence of nitrogen on cell division, cell elongation, cell expansion synthesis, of amino acids, enzymes and chlorophyll which might increase the root length. The results are in agreement with the findings of Houchmuth ${ }^{12}$ who noted that the application of NPK fertilizer significantly increased the root length in radish (Figure 2).

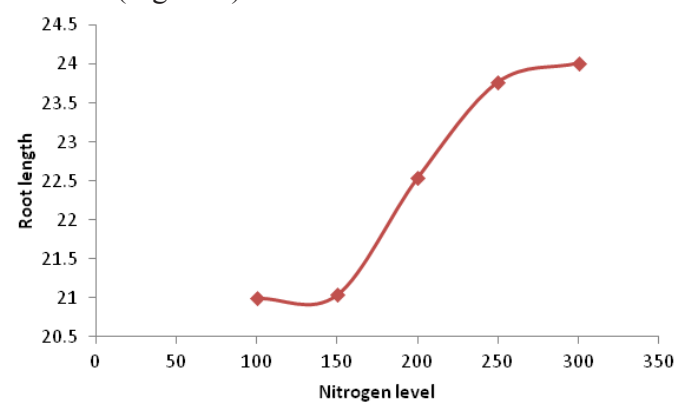

Figure 2 Relationship between root length and different nitrogen level of Radish at Lamjung Agriculture Campus, Lamjung, Nepal during Oct 2017- Jan 2018.

\section{Effect of nitrogen level in root weight}

The results entails that there is no difference in the effect of nitrogen on root weight. As in previous research in temperate regions showing little response of carrot to applied $\mathrm{N},{ }^{13-16}$ carrot yield did not respond to $\mathrm{N}$ application rate or preplant available $\mathrm{N}$ on organic soil. In addition to this, it have a deep and extensive root system ${ }^{17,18}$ and may be accessing residual $\mathrm{N}$ applied the previous season that has leached into lower levels of soil profile.

\section{Effect of nitrogen level in root girth}

The results entails that there is no difference in the effect of nitrogen on root girth. The results are in conformity with Bloom 
$\mathrm{AJ}^{19}$ that the growth-promoting effect of $\mathrm{N}$ (up to the optimum level) increases cytokinin production, which subsequently affects cell wall elasticity, number of meristematic cells, and cell growth. In contrary, Higher $\mathrm{N}$ level provided more $\mathrm{N}$ and more space for the development of root which resulted in maximum diameter that is applicable up to certain limit, further increment will decrease the diameter. ${ }^{18}$

\section{Conclusion}

Nitrogen dose of $250 \mathrm{~kg} / \mathrm{ha}$ and $300 \mathrm{Kg} / \mathrm{ha}$ in radish is significantly better than other dose for providing increased plant height with longest radish root. Future studies should be directed to determine the relationship in multiple location and multiple seasons.

\section{Acknowledgements}

I feel the inadequacy of diction in expressing my sincere gratitude towards my respected Advisor Mr. Ram Kumar Shrestha and Coadvisor Mr. Amit Khanal for conceptualization of the subject and continuous guidance and thank my Campus Chief of IAAS, Lamjung Campus, Dr. Bishnu Bilash Adhikari, RD-Tec lamjung Campus and my dearest friends of Pathology and Soil group for their intense support throughout my research period.

\section{Conflict of interest}

Author declares that there is no conflict of interest.

\section{References}

1. Poon TB, Regmi HN, Woli OB. Influence of plant spacing on seed yield of radish Mino Early. In: Khatri BB, Sharma BP, Khatiwada PP, et al, editors. Proceedings of the fourth national workshop on horticulture (2-4 March 2004). Khumaltar: Nepal Agri Res Council; 2004;373-376.

2. Hussain I, Haq I, Sajid M, et al. Effect of nitrogen alone and in combination with constant doses of potassium on yield of radish. Sarhad J Agric. 1997;13:39-43.

3. Kowalska I, Sady W, Shura A. Effect of of forms of nitrogen fertilizer, foliar feeding and place of cultivation on the yield and quality of lettuce. Acta Agrophysica. 2006;7(3):619-631.

4. Pervez MA, Ayub CM, Saleem BA. Effect of nitrogen levels and spacing on growth and yield of radish (Raphanussativus L.). Int J Agri Biol. 2004;06(3):504-506.

5. Brintha I, TH Seran. Effect of paired row growth and yield of Turnip (Brassica campestris var. planting of radish (Raphanussativus L.) intercropped Rapifera). Bangladesh Research Publications Journal. 2009.
6. Sharma SK, Rastogi KB. Effect of nitorgen nutrient and spacing on seed production of cut flowers. Indian J Hort. 1992;49: 274-276.

7. Balooch B. Study of the relationship between relative growth rate and NPK content during Radish (Raphanussativus L) growth: Effects of nutrient and radiation levels. Journal of Agronomy. 1998;16:529539. 13.

8. Sharma S K, Kanavjia SP. Influence of transplanting dates of stecklings and nitrogen levels on seed production of radish (Raphanussativus L.). Seed Res. 1994;20:92-95.

9. Shrivastava BK, Singh MP, Jain SK. Effect of spacing and nitrogen levels on growth, yield and quality of seed crops of radish. Seed Res. 1992;20:85-87.

10. Nargave K. Effect of Genotypes and Nutrient Levels on Growth, Yield and Quality of Radish (RaphanusSativus L.). Rajmata Vijayaraje Scindia Krishi Vishwa Vidyalaya; India:2016.

11. Parthasarathi KS, Krishnappa K, Gowda MC, et al. Growth and yield of certain radish varieties to varying levels of fertility. Karnataka J Agri Sci. 1999;12:148-153.

12. Hochmuth GJ, Brecht JK, Bassett MJ. Nitrogen fertilization to maximize carrot yield and quality on a sandy soil. Hort Sci. 1999;34(4):641-645.

13. Hamilton HA, Bernier R. N-P-K fertilizer effects on yield, composition and residues of lettuce, celery, carrot and onion grown on an organic soil in Quebec. Can J Plant Sci. 1975;55(2):453-461.

14. Wiebe HJ. Effects of plant densities and nitrogen supply on yield harvest date and quality of carrots. Acta Horticulturae. 1987;198:191-198.

15. Warncke DD. Soil and plant tissue testing for nitrogen management in carrots. Commun Soil Sci Plant Anal. 1996;27:597-605.

16. Westerveld SM, McDonald MR, Scott Dupree CD, et al. The effect of nitrogen on insect and disease pests of onions, carrots, and cabbage. Journal of Vegetable Crop Production. 2003;8(2):87-99.

17. Thorup Kristensen K, van den Boogaard R. Vertical and horizontal development of the root system of carrots following green manure. Plant and Soil. 1999;212(2):145-153.

18. Westerveld SM, McDonald MR, Scott Dupree CD, et al. Assessment of a nitrate meter for nitrogen tests in mineral and organic soils. J Vegetable Sci in press. 2006;11(3):17-32.

19. Bloom AJ. Influence of Inorganic Nitrogen and $\mathrm{pH}$ on the elongation of maize seminal roots. Ann Bot. 2006;97(5);867-873. 